\title{
Prevalence of Hepatitis C Virus and Associated Risk Factors among Inmates at New Bell Prison, Douala, Cameroon
}

\author{
Mathurin Pierre Kowo ${ }^{1}$, Firmin Ankouane Andoulo ${ }^{1}$, Larry Tangie Ngek ${ }^{1}$, \\ Daniel Tchamdeu Sizimboue ${ }^{2}$, Antonin Ndjitoyap Ndam', Buno Ela Ondo ${ }^{2}$, \\ Servais Eloumou Bagnaka3 ${ }^{3}$ Rocard Djanteng4, Elie-Claude Ndjitoyap Ndam¹, Oudou Njoya1 \\ ${ }^{1}$ Department on Internal Medicine and Specialities, Faculty of Medicine and Biomedical Sciences, University of Yaoundé I, \\ Yaoundé, Cameroon \\ ${ }^{2}$ Université des Montagnes, Banganté, Cameroon \\ ${ }^{3}$ Faculty of Medicine and Pharmaceutical Sciences, University of Douala, Douala, Cameroon \\ ${ }^{4}$ Medical Center, New Bell Prison, Douala, Cameroon \\ Email: *kowomathurinp@yahoo.fr, ankouaneandoulo@yahoo.com, ngeklatan@yahoo.com, tchamdeudaniel@yahoo.fr, \\ tonindam3@yahoo.fr, elaondo@yahoo.fr,eloumoug@yahoo.fr, rdjanteng@yahoo.fr, ecndam@yahoo.fr, oudou_njoya@yahoo.fr
}

How to cite this paper: Kowo, M.P., Andoulo, F.A., Ngek, L.T., Sizimboue, D.T., Ndam, A.N., Ondo, B.E., Bagnaka, S.E., Djanteng, R., Ndam, E.-C.N. and Njoya, O. (2019) Prevalence of Hepatitis C Virus and Associated Risk Factors among Inmates at New Bell Prison, Douala, Cameroon. Open Journal of Epidemiology, 9, 119-128. https://doi.org/10.4236/ojepi.2019.92011

Received: February 13, 2019

Accepted: May 3, 2019

Published: May 6, 2019

Copyright $\odot 2019$ by author(s) and Scientific Research Publishing Inc. This work is licensed under the Creative Commons Attribution-NonCommercial International License (CC BY-NC 4.0). http://creativecommons.org/licenses/by-nc/4.0/ (c) (i) \& Open Access

\begin{abstract}
Although a high prevalence of HCV infection in correctional facilities has been well reported in several countries around the world, there has been no such data from Cameroon. The aim of this study was to determine the prevalence and factors associated with viral hepatitis $C$ seropositivity among prisoners incarcerated at the New Bell Central Prison in Douala. From the $2^{\text {nd }}$ to the $27^{\text {th }}$ of July 2018,940 inmates selected using a systematic random sampling method were interviewed to collect data on sociodemographic status, duration of incarceration, number of incarcerations and risk factors for $\mathrm{HCV}$ transmission. Blood samples were collected for screening of anti-HCV antibodies via HEPA-SCAN HCV CARD Test. Positive samples had a confirmatory ELISA test. Data were analysed using EPI DATA 4.4.0.0 software. Statistical significance was set at a $\mathrm{p}<0.05$. Of the 940 prisoners selected, $94.1 \%$ (884) were males. The mean age of the study population was $33.81 \pm 10.35$ years (extremes: 14 and 74 years). HCV prevalence was $4.4 \%$ (40). The use of non-injectable illicit drugs (OR $2.8795 \%$ CI $1.44-5.73)(\mathrm{p}=0.002)$ but not injectable illicit drugs (OR $1.9195 \%$ CI $0.43-8.41)(\mathrm{p}=0.42$ ), male homosexuality (OR $17.4595 \%$ CI 7.58 - 40.13) ( $\mathrm{p}<0.001)$, sharing of needles (OR $3.4595 \%$ CI $1.59-7.83)(\mathrm{p}=0.001)$, past history of tattooing or piercing (OR $5.9495 \%$ CI $2.80-12.16)(\mathrm{p}<0.001)$ and age $\geq 50$ (OR 4.069; 95\% CI 1.9 8.68) $(\mathrm{p}=0.003)$ were significantly associated with HCV antibodies positivity. Inmates in New Bell Central Prison accumulate risk factors for viral hepatitis
\end{abstract}


$\mathrm{C}$, thus contributing to the high prevalence in this setting. Control strategies and programs that reach this particular population should urgently be implemented.

\section{Keywords}

Prevalence, Risks factors, Hepatitis C, Prisoners

\section{Introduction}

Hepatitis $\mathrm{C}$ virus (HCV) infection is a major public health problem in the world with significant mortality and morbidity especially in Sub Saharan African and East Asian countries [1]. In 2015, WHO estimated at 71 million the number of people chronically infected by HCV worldwide [1]. About 1.75 million people newly acquire hepatitis $C$ virus infection each year. Hepatitis $C$ and $B$ viruses related death is about 1.3 million every year mainly due to liver cirrhosis and/or hepatocellular carcinoma (HCC) [1].

With a general population $\mathrm{HCV}$ prevalence estimated at $6.5 \%$, Cameroon is considered as one of the most affected countries in the world [2].

Prisoners are a high risk population for infectious diseases with a high prevalence for viral hepatitis and HIV. Overall prevalence of HCV infection ranging from $0.2 \%$ to $13 \%$ has been reported by several studies in Europe [3] [4] [5], North America [6], Latino America [7] and Africa [8] among adult inmates. This high risk is linked to the prison setting with poor hygiene, promiscuity, malnutrition, tattooing and other forms of skin piercing, physical and moral violence, intravenous drug use, homosexuality and lack of knowledge about HCV transmission modes as reported by several authors [9] [10]. Being incarcerated for longer period or having more than one incarceration has also been associated to HCV infection [9] [11].

In addition prisoners suffered from limited access to appropriate health care services, lack of early detection and treatment of some chronic disease could serve as reservoirs for $\mathrm{HCV}$ infections.

Despite the high prevalence HCV infection in Cameroon, published data on the prison setting are scarce. The aim of this study was to determine the prevalence of HCV antibodies and their associated risk factors among inmates of the New Bell central prison Douala in Cameroon.

\section{Materials and Methods}

\subsection{Study Design}

This was a cross sectional study from the $2^{\text {nd }}$ to the $27^{\text {th }}$ of July 2018 at the New Bell central prison including 940 inmates obtained by systematic random sampling from a total of 3356 inmates present during the study period. The participants were arranged alphabetically and selected using a sampling interval of 4 . 
Data collected included age, gender, profession before detention, level of education, marital status, religion, number, quarter and duration of incarceration. Data on risk factors for HCV transmission was equally collected on a pretested questionnaire. Detection of anti HCV antibodies was done using HEPA-SCAN HCVCARD (RECKON DIAGNOSTICS P.LTD (3/7, BIDC, Gorwa Vadogara 390,016 (INDIA)) which is a rapid diagnostic test for detection of anti HCV antibodies in plasma and serum. Inmates who tested positive had a confirmatory ELISA test.

\subsection{Study Setting}

Created in 1930, the New Bell prison in Douala is one of the two largest prisons in Cameroon. It is a mixed prison with separate male, female and children quarters. It has a capacity of 960 places for over 3500 prisoners with 27 cells containing between 30 - 200 prisoners per cell giving an average space of $0.2 \mathrm{~m}^{2}$ per inmate for a standard of $0.4 \mathrm{~m}^{2}$. The New Bell central prison is divided into 10 quarters which harbours 4 different groups of persons; Minors (males less than 18 years of age), aged persons (males above 55 years of age), females of all age groups and males between 18 and 54 years of age. Males between 18 and 54 years constitute $86.7 \%$ of all inmates.

The prison offers health services for inmates and has 1 medical doctor, 2 state registered nurses, 5 assistant nurses and 2 laboratory technicians. All new prisoners have complete physical examination by the site physician with systematic HIV screening but no screening for viral hepatitis is done despite the precarious conditions in this setting.

\subsection{Data Analysis}

The Statistical Package for Social Sciences (SPSS) version 21.0 (Institute, Cary, NC, USA) was used for data analysis. The odds ratio (OR) and the $95 \%$ confidence interval ( $95 \% \mathrm{CI})$ were calculated to assess associations between HCV antibodies positivity and sociodemographic variables, some accepted risk factors for HCV infection in univariate analysis. Independent associations were evaluated by calculating the adjusted OR by multivariate analysis for the sociodemographic variables and the risk factors found to be significant in the univariate analysis. A $P$ value of $<0.05$ was considered significant.

\subsection{Ethical Considerations}

Ethical clearance was obtained from institutional ethical review board of the University of Montagne Banganté Cameroon while administrative authorization was procured from the regional delegate for penitentiary administration Littoral region and the superintendent in charge of the New Bell central prison. Prison inmates tested positive for $\mathrm{HCV}$ antibodies were then referred to the medical doctor in charge of the prison health service for proper management. All included inmates signed a written consent form. 


\section{Results}

Of the 940 prisoners included, $94.1 \%$ (884) were males and 5.9\% (56) were females (Table 1 ). The mean age was 33.81 years ( \pm 10.35 years) with extremes of 14 and 74 years. The most represented age group was 30 - 39 years with $41.1 \%$ of cases (Table 1). Prevalence of HCV antibodies was 4.4\% (40) (Table 2). Among the 940 prisoners, $60 \%$ (566) were unaware of HCV infection and risk factors for HCV transmission (Table 3 ).

Table 4 and Table 5 showed the Odd ratios for HCV antibodies positivity according to socio-demographic characteristics and some risk factors of HCV among new bell prison inmates in Douala. Inmates aged 50 years and above

Table 1. Baseline socio-demographic characteristics of the study population.

\begin{tabular}{|c|c|c|}
\hline Characteristics & Number & Percentage (\%) \\
\hline \multicolumn{3}{|l|}{ Gender } \\
\hline Male & 884 & 94 \\
\hline Female & 56 & 6 \\
\hline \multicolumn{3}{|l|}{ Age (years) } \\
\hline$[10-19]$ & 58 & 6.2 \\
\hline [20 - 29] & 270 & 28.9 \\
\hline [30 - 39] & 385 & 41.1 \\
\hline$[40-49]$ & 148 & 15.8 \\
\hline$\geq 50$ & 78 & 8.3 \\
\hline $\begin{array}{l}\text { Level of education } \\
\text { Never to primary }\end{array}$ & 629 & 66.9 \\
\hline Secondary and above & 311 & 33.1 \\
\hline \multicolumn{3}{|l|}{ Marital status } \\
\hline Single & 560 & 59.5 \\
\hline Married & 368 & 39.2 \\
\hline Widow & 12 & 1.3 \\
\hline \multicolumn{3}{|l|}{ Religion } \\
\hline Christian & 704 & 74.7 \\
\hline Muslim & 200 & 21.2 \\
\hline Others & 36 & 3.8 \\
\hline \multicolumn{3}{|l|}{ Profession } \\
\hline Private sector & 400 & 42.7 \\
\hline Civil servant & 114 & 12.2 \\
\hline Trader & 193 & 20.6 \\
\hline Student & 99 & 10.6 \\
\hline Farmer & 25 & 2.7 \\
\hline Unemployed & 103 & 11 \\
\hline
\end{tabular}


Table 2. Prevalence of HCV antibodies.

\begin{tabular}{ccc}
\hline Serology & Number & Percentage (\%) \\
\hline Positive HCV Ab & 40 & 4.4 \\
Negative HCV Ab & 900 & 85.6 \\
\hline
\end{tabular}

Table 3. Knowledge on HCV infection and risk factors for transmission.

\begin{tabular}{ccc}
\hline & Number & Percentage (\%) \\
\hline Yes & 374 & 39.8 \\
No & 566 & 60.2 \\
Total & 940 & 100 \\
\hline
\end{tabular}

Table 4. Odd ratio for HCV antibodies positivity according to socio-demographic and carceral characteristics among New bell prison inmates in Douala.

\begin{tabular}{|c|c|c|c|c|c|c|c|}
\hline Characteristics & $\begin{array}{l}\text { Number } \\
\text { tested }\end{array}$ & $\begin{array}{l}\text { HCV Ab positive } \\
\mathrm{N}(\%) £\end{array}$ & $\begin{array}{c}\text { HCV Ab negative } \\
\text { N (\%) } ¥\end{array}$ & OR (95\% IC) & $P$ value & Adjusted OR & $\begin{array}{l}\text { Adjusted } \\
\text { P-value }\end{array}$ \\
\hline \multicolumn{8}{|l|}{ Gender } \\
\hline Male & 883 & $38(95)$ & $845(93.8)$ & $1.21(0.28-5.16)$ & 0.787 & $1.12(0.22-5.59)$ & 0.892 \\
\hline Female & 56 & $2(5)$ & $56(6.2)$ & & & & \\
\hline \multicolumn{8}{|l|}{ Age (years) } \\
\hline [10 - 19] & 58 & $0(0)$ & $58(0)$ & $0.39(0.11-2.97)$ & 0.319 & & \\
\hline [20 - 29] & 271 & $2(5)$ & $269(28.8)$ & $0.56(0.11-2.17)$ & 0.551 & & \\
\hline [30 - 39] & 385 & $13(32.5)$ & $372(41.3)$ & $0.79(0.32-2.21)$ & 0.261 & & \\
\hline$[40-49]$ & 148 & $8(20)$ & $140(15.5)$ & $2.27(0.3-22.21)$ & 0.465 & & \\
\hline$\geq 50$ & 78 & $17(42.5)$ & $61(6.7)$ & $4.069(1.90-8.68)$ & 0.001 & $3.89(1.56-9.68)$ & 0.003 \\
\hline \multicolumn{8}{|l|}{ Level of education } \\
\hline Never to primary & 628 & $29(72.5)$ & $599(66.5)$ & $1.32(0.65-2.68)$ & 0.433 & & \\
\hline Secondary and above & 311 & $11(27.5)$ & $30(3.3)$ & & & & \\
\hline \multicolumn{8}{|l|}{$\begin{array}{c}\text { Duration of } \\
\text { incarceration (months) }\end{array}$} \\
\hline$>12$ & 465 & $33(82.5)$ & $432(48)$ & $5.05(2.12-11.54)$ & $<0.001$ & $5.17(2.16-12.35)$ & 0.002 \\
\hline$\leq 12$ & 471 & $7(17.5)$ & $463(51.4)$ & & & & \\
\hline \multicolumn{8}{|l|}{$\begin{array}{c}\text { Number of } \\
\text { incarcerations }\end{array}$} \\
\hline$\geq 2$ & 250 & $9(22.5)$ & $241(26.7)$ & $0.79(0.37-1.69)$ & 0.54 & $0.443(0.19-1.011)$ & 0.57 \\
\hline 1 & 690 & $31(77.5)$ & $660(73.1)$ & & & & \\
\hline
\end{tabular}

$\mathfrak{E}$ : percentage according to total number of patients positive for HCV antibodies; ¥: percentage according to total number of patients negative for HCV antibodies.

Table 5. Odd ratio and adjusted odd ratio for HCV antibodies according to risk factors among new bell prison inmates in Douala.

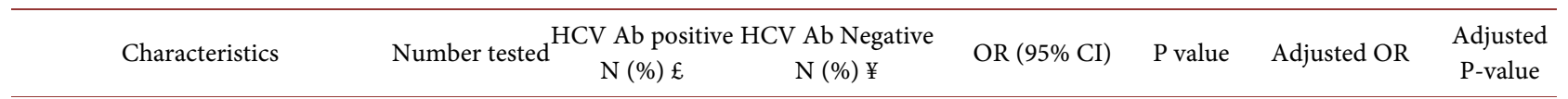

Poor knowledge on risk

factors of HCV transmission 


\section{Continued}

$\begin{array}{lccccc}\text { NO } & 625 & 29(72.5) & 596(66.1) & 1.35(0.66-2.73) & 0.495 \\ \text { YES } & 315 & 11 & 304 & & \end{array}$

Injected illicit drugs used

$\begin{array}{lccccccc}\text { YES } & 26 & 2(5) & 24(2.6) & 1.91(0.43-8.41) & 0.42 & 2.21(0.37-10.94) & 0.49 \\ \text { NO } & 913 & 38 & 875 & & & & \end{array}$

Non injected illicit drugs used $¥ ¥$

$\begin{array}{lccccccc}\text { YES } & 430 & 28(70) & 402(44.7) & 2.87(1.44-5.73) & 0.002 & 1.87(0.85-4.093) & 0.119 \\ \text { NO } & 508 & 12 & 496 & & & \end{array}$

Men having sex with men

$\begin{array}{lcccccc}\text { YES } & 31 & 11(27.5) & 20(2.2) & 17.45(7.58-40.13)<0.001 & 3.831(1.65-8.84) & 0.002 \\ \text { NO } & 908 & 29 & 879 & & \end{array}$

Sharing of needles,

razors or teeth brushes

YES

NO

271

664

35 (87.5)

5

$236(26.1)$

$3.45(1.59-7.83) \quad 0.001 \quad 2.74(1.14-6.54)$

0.025

History of tattooing or piercing

YES

NO

$31(77.5)$

$329(36.4)$

$5.94(2.80-12.66)<0.0013 .831(1.65-8.84)$

0.002

9

567

History of scarifications

YES

NO

391

$36(90)$

$355(39.4)$

$13.76(4.85-29.01)<0.001 \quad 10.28(3.51-22.08)<0.001$

549

4

545

History of blood transfusion

YES

115

7 (17.5)

108

$1.55(0.67-3.59)$

0.320

$1.10(0.43-2.82)$

0.832

825

33

792

$£$ : percentage according to total number of patients positive for HCV antibodies; $¥$ : percentage according to total number of patients negative for HCV antibodies; ¥¥: non-injectable illicit drugs were marijuana, cocaine.

were at increased risk of HCV infection (OR 4.069; 95\% CI 1.9 - 8.68) ( $\mathrm{p}=$ 0.003 ) as compared to younger patients. Being incarcerated for more than one time was not associated with high risk of HCV seropositivity (OR 0.79; 95\% CI 0.37 - 1.69) $(\mathrm{p}=0.54)$. However the duration of incarceration greater than 12 months had 5.05 fold (95\% CI 2.12 - 11.54) higher risk of HCV transmission. In univariate analysis, use of non-injectable illicit drugs (OR 2.87 95\% CI 1.44 5.73) ( $\mathrm{p}=0.002)$ but not injectable illicit drugs (OR $1.9195 \%$ CI $0.43-8.41)(\mathrm{p}=$ 0.42 ), male homosexuality (OR $17.4595 \%$ CI $7.58-40.13$ ) ( $<<0.001$ ), sharing of needles (OR $3.4595 \%$ CI $1.59-7.83)(\mathrm{p}=0.001)$ and past history of tattooing or piercing (OR $5.9495 \%$ CI 2.80 - 12.16) ( $\mathrm{p}<0.001)$ were all significantly associated with HCV antibodies positivity. Nevertheless, in multivariate analysis, the use of non-injectable illicit drugs was no longer associated to HCV transmission (adjusted OR 1.87 95\% CI 0.85 - 4.09) ( $\mathrm{p}=0.119)$. 
Inmates with past history of blood transfusion had 1.55 fold (OR $1.5595 \% \mathrm{CI}$ 0.67 - 3.59 higher risk factor for HCV transmission but this was not significant $(\mathrm{p}=0.32)$.

\section{Discussion}

Hepatitis $\mathrm{C}$ virus $(\mathrm{HCV})$ is a major public health problem in different part of the world especially in developing countries. With an estimated overall pooled HCV seroprevalence of $6.5 \%$, Cameroon is considered as one of the most infected countries in the world and the burden of disease varies from one group to the other [2]. Prison inmates represent one of the high risk population groups. Overcrowding in prisons and some high risk behaviours such as injecting drug use, tattooing high risk sexual behaviour are factors that could favour the transmission of infectious diseases such as viral hepatitis, HIV and other sexually transmissible diseases. Published data on prison inmates in Cameroon are rare. Therefore the aim of this study was to determine the prevalence and factors associated with HCV antibodies positivity among prison inmates at the New Bell Central Prison Douala.

Our study population was predominantly male $(94.1 \%)$ with a mean age of $33.81 \pm 10.35$ years. The most represented age group was that between 30 and 39 years.

The prevalence of HCV antibodies in our study population was estimated at 4.4\%.The seroprevalence of HCV infection in the general population in Cameroon is still a matter of concern. Up to now no nationwide representative study has provided better estimates of the seroprevalence of HCV in the country. A recent meta-analysis on 31 studies including 36407 individuals from different groups has reported an overall pooled HCV seroprevalence of 6.5\% [2] that was higher compared to the $2.5 \%$ reported by Njouom et al. in 2018 [12] in patients aged between 15 - 59 years. In most published studies in Cameroon HCV seroprevalence is higher in older population and the low prevalence reported by Njouom et al. could be explained by the fact that they do not included patients of more than 60 years. Nevertheless, HCV seroprevalence of $4.4 \%$ reported in this study is high and could be explained by the presence of several risk factors for $\mathrm{HCV}$ transmission in our prison setting including homosexuality, scarifications, sharing of toiletries, both intravenous and non-intravenous drug use, history of tattooing and piercing.

About half $(48.6 \%)$ of our study population admitted drug use with the non-injectable form being the most frequently used despite strict security rules instituted by the penitentiary authorities. This finding is consistent with that reported by Adjei et al. [13] in Ghana in 2006 with non-injectable drug use being the most common form of drug abuse. Only $2.7 \%$ of our study population admitted intravenous drug use before incarceration which could be explained by the scarcity and expensive nature of these drugs in our setting and similar to reports from other African prisons [8] [13] [14]. The HCV prevalence obtained in 
our study is however lower than that reported in European series where epidemic patterns of HCV infection related to injection drug use persists among prisoners. Dolan K et al. [15] in 2016 reported HCV prevalence's of $20.2 \%$ in eastern Europe and central Asia region, $15.5 \%$ in west Europe and $15.3 \%$ in North America. This high prevalence's could be attributed to high intravenous drug use with sharing of needles among prisoners in the developed world. Several authors [16] [17] [18] have reported a direct link between high HCV prevalence and intravenous drug use. Hence the absence of IVDU in our study population suggests other routes of contamination especially the sexual route.

HCV infection was significantly associated with homosexuality $(\mathrm{p}<0.001)$, sharing of toiletries $(p=0.001)$, scarifications $(p<0.001))$ and duration of incarceration $(\mathrm{p}<0.001)$.

These findings are similar to those reported by Adoga et al. in 2006 in Nigeria [8] who found duration in prison to be associated with HCV transmission. In our study population, prisoners between 12 - 36 months of incarceration were more at risk for HCV transmission. Homosexuality especially among men increases by 17 folds the risk of having HCV infection. This finding is consistent with the reports from other authors [9] [19]. In the prison milieu, overcrowding and precarious conditions with increased promiscuity favours this practice which is well known as risk factor of HCV infection. Sharing of toiletries $(\mathrm{p}=$ $0.001)$, history of tattoos/piercing $(\mathrm{p}<0.001)$, scarifications $(\mathrm{p}<0.001)$ were also significantly associated with HCV infection. However about $60 \%$ of the study population was unaware of this means of $\mathrm{HCV}$ transmission.

\section{Conclusion}

Inmates in New Bell Central Prison accumulate risk factors for viral hepatitis $\mathrm{C}$, thus contributing to the relatively high prevalence in this setting. In the aim to eradicate HCV infection, there is an urgent need to implement a viable health policy to manage high risk populations like these prisoners.

\section{Acknowledgements}

The authors thank the superintendent in charge of the New Bell central prison, the regional delegate for penitentiary administration Littoral region for the assistance during the study and all members of SOS Hépatites Douala who offered facilities in the Laboratory.

\section{Authors' Contributions}

This work was carried out in collaboration between all authors. Author MK contributed in collection of data, analysis and editing the article; Author FA contributed in study conception, analysis of data and editing the article. Author DT wrote the protocol, collected data. Authors LT, AN, BE, SE, RD contributed in collection of data and revised the first draft of the manuscript. Authors ECN and ON supervised all the activities and approved the final version to be sub- 
mitted for publication. All authors read and approved the final manuscript.

\section{Funding}

None.

\section{Ethical Considerations}

Ethical clearance was obtained from institutional ethical review board of the University of Montagne Banganté Cameroon while administrative authorization was procured from the regional delegate for penitentiary administration Littoral region and the superintendent in charge of the New Bell central prison. Prison inmates tested positive for HCV antibodies were then referred to the medical doctor in charge of the prison health service for proper management. All included inmates signed a written consent form.

\section{Conflicts of Interest}

Authors have declared that no competing interests exist.

\section{References}

[1] World Health Organization (2017) Global Hepatitis Report, 2017. Geneva. http://www.WHO.int/hepatitis/publications/global-hepatitis-report2017/en

[2] Bigna, J.J., AmougouAtsama, M., LemAsangbeh, S., MalahaKenne, A., Noumegni, S., et al. (2017) Seroprevalence of Hepatitis C Virus Infection in Cameroon: A Systematic Review and Meta-Analysis. BMJ Open, 7, e015748. https://doi.org/10.1136/bmjopen-2016-015298

[3] Chacowry, K., Baggio, S., Toan, N., Girardin, F., Wolff, H. and Gétaz, L. (2018) Blood-Borne and Sexually Transmitted Infections: A Cross-Sectional Study in a Swiss Prison. BMC Infectious Diseases, 18, 539. https://doi.org/10.1186/s12879-018-3445-6

[4] Tresó, B., Barcsay, E., Tarján, A., Horváth, G., Dencs, Á., Hettmann, A., et al. (2012) Prevalence and Correlates of HCV, HVB, and HIV Infection among Prison Inmates and Staff, Hungary. Journal of Urban Health: Bulletin of the New York Academy of Medicine, 89, 108-116. https://doi.org/10.1007/s11524-011-9626-x

[5] Gétaz, L., Casillas, A., Siegrist, C.-A., Chappuis, F., Togni, G., et al. (2018) Hepatitis B Prevalence, Risk Factors, Infection Awareness and Disease Knowledge among Inmates: A Cross-Sectional Study in Switzerland's Largest Pre-Trial Prison. Journal of Global Health, 8, Article ID: 020407. https://doi.org/10.7189/jogh.08.020407

[6] Hennessey, K., Kim, A., Griffin, V., Collins, N., Weinbaum, C. and Sabin, K. (2009) Prevalence of Infection with Hepatitis B and C Viruses and Co-Infection with HIV in Three Jails: A Case for Viral Hepatitis Prevention in Jails in the United States. Journal of Urban Health: Bulletin of the New York Academy of Medicine, 86, 93-105. https://doi.org/10.1007/s11524-008-9305-8

[7] Barros, L., Carolina, G., Araújo, S., Maria, S., André, M., Maria, R., et al. (2013) Epidemiology of the Viral Hepatitis B and C in Female Prisoners of Metropolitan Regional Prison Complex in the State of Goiás, Central Brazil. Revista da Sociedade Brasileira de Medicina Tropical, 46, 24-29.

https://doi.org/10.1590/0037-868216972013 
[8] Adoga, M.P., Banwat, E.B., Forbi, J.C., Nimzing, L., Pam, C.R., Gyar, S.D., et al. (2009) Human Immunonodeficiency Virus, Hepatitis B Virus and Hepatitis C Virus: Seroprevalence, Co-Infection and Risk Factors among Prison Inmates in Nasarawa State, Nigeria. The Journal of Infection in Developing Countries, 3, 539-547. https://doi.org/10.3855/jidc.472

[9] Adjei, A.A., Armah, H.B., Gbagbo, F., Ampofo, W.K., Quaye, I.K., Hesse, I.F. and Mensah, G. (2007) Correlates of Hepatitis C Virus Infection among Incarcerated Ghanaians: A National Multicentre Study. Journal of Medical Microbiology, 56, 391-397. https://doi.org/10.1099/jmm.0.46859-0

[10] Babudieri, S., Longo, B., Sarmati, L., Starnini, G., Dori, L., Suligoi, B., Carbonara, S., Monarca, R., Quercia, G., Florenzano, G., Novati, S., Sardu, A., Iovinella, V., Casti, A., Romano, A., Uccella, I., Maida, I., Brunetti, B., Mura, M.S., Andreoni, M. and Rezza, G. (2005) Correlates of HIV, HBV, and HCV Infections in a Prison Inmate Population: Results from a Multicentre Study in Italy. Journal of Medical Virology, 76, 311-317. https://doi.org/10.1002/jmv.20375

[11] Guimarães, T., Granato, C.F.H., Varella, D., et al. (2001) High Prevalence of Hepatitis C Infection in a Brazilian Prison: Identification of Risk Factors for Infection. The Brazilian Journal of Infectious Diseases, 5, 111-118. https://doi.org/10.1590/S1413-86702001000300002

[12] Njouom, R., Siffert, I., Texier, G., et al. (2018) The Burden of Hepatitis C Virus in Cameroon: Spatial Epidemiology and Historical Perspective. Journal of Viral Hepatitis, 25, 959-968. https://doi.org/10.1111/jvh.12894

[13] Adjei, A.A. (2006) Prevalence of Human Immunodeficiency Virus, Hepatitis B Virus, Hepatitis C Virus and Syphilis among Prison Inmates and Officers at Nsawam and Accra, Ghana. Journal of Medical Microbiology, 55, 593-597. https://doi.org/10.1099/jmm.0.46414-0

[14] Jaquet, A., Wandeler, G., Tine, J., Dagnra, C.A., Attia, A., Patassi, A., et al. (2016) HIV Infection, Viral Hepatitis and Liver Fibrosis among Prison Inmates in West Africa. BMC Infectious Diseases, 16, 249. https://doi.org/10.1186/s12879-016-1601-4

[15] Dolan, K., Wirtz, A.L., Moazen, B., Ndeffo-mbah, M., Galvani, A., Kinner, S.A., et al. (2016) Global Burden of HIV, Viral Hepatitis, and Tuberculosis in Prisoners and Detainees. The Lancet, 388, 1089-102. https://doi.org/10.1016/S0140-6736(16)30466-4

[16] Stasi, C., Silvestri, C., Fanti, E., Fiandra, T.D. and Voller, F. (2016) Prevalence and Features of Chronic Viral Hepatitis and HIV Coinfection in Italian Prisons. European Journal of Internal Medicine, 34, e21-e22. https://doi.org/10.1016/j.ejim.2016.04.020

[17] Azbel, L., Wickersham, J.A., Grishaev, Y., Dvoryak, S. and Altice, F.L. (2013) Burden of Infectious Diseases, Substance Use Disorders, and Mental Illness among Ukrainian Prisoners Transitioning to the Community. PLoS ONE, 8, e59643. https://doi.org/10.1371/journal.pone.0059643

[18] Lemoine, M., Eholié, S. and Lacombe, K. (2015) Reducing the Neglected Burden of Viral Hepatitis in Africa: Strategies for a Global Approach. Journal of Hepatology, 62, 469-476. https://doi.org/10.1016/j.jhep.2014.10.008

[19] Falla, A.M., Hofstraat, S.H.I., Duffell, E., Hahné, S.J.M., Tavoschi, L. and Veldhuijzen, I.K. (2018) Hepatitis B/C in the Countries of the EU/EEA: A Systematic Review of the Prevalence among At-Risk Groups. BMC Infectious Diseases, 18, 79. https://doi.org/10.1186/s12879-018-2988-x 